論 文

\title{
近代都市職人の生活世界
}

坪田典子・水越紀子

\section{1. 問題の所在}

本稿では、一人の都市職人によって書かれた日記(以下、米沢日記)をデータとして、近 代日本の地方中心都市における職人の生活世界の分析と解採を試みる。米沢日記には、明 治・大正・昭和を生きた象嵌 ${ }^{11}$ 職人米沢弘妿と妻芳野を中心とした日常生活が描かれて いる。その中には、家父長制的「家」規範から距離をおいた生活世界の記述が随所にみら れる。そこに見られる規範からの距離の意味や内容、距離の取り方等に関心を呼び覚まさ れたのが本稿の出発点である。

ここで問題とする「家」は、日本の家族史や女性史さらには日本の歴史一般を考える上 でも避けて通れない理念/実態をあらわす重要な概念であり、近年、近代家族論の立場か らも「家」を近代家族論にどう位置づけるかといら議論が展開されている。近代家族論は、 近代 (明治から戦前期) のいわゆる家制度下の家族が近代家族的な性格を持っていたことを 論証してきた[小山，1991；牟田，1996 等]。しかし、これをさらに押し進めて上野(1994) は、「家」は明治政府の所産 (近代家族）[p. 69，p. 94] と主張し、それに対し落合 (1996) は、 明治以前にも広く「家」が成立していた[pp. 42-43]として反論している。両者の論点は、

「家」は近代の所産 (近代家族)が゙うかという点にある。ここで上野を「家＝近代家族」 一元論であるとすると、落合は「家」は「近代家族」には解消できないとする立場から「家」 と「近代家族」といらふたつの概念を別物とし、それらの間の相互作用を論ずる二元論の 立場をとる[落合, p. 43]。

上野は、その論拠として明治民法以前の地域的多様性をあげ、「各地の慣習法の中に母 系相続や末子相続等が存在していた」[p. 70]こと、また『家』は庶民には無縁のもので あった」[p. 130]ことを述べおりり、他方、落合は、「17 世紀後期から 18 世紀にかけて農 民の間にも家産·家業·家名を継承し、先祖を祭祀する家が広く成立したといわれている」 [pp. 42-43]こと等から、「家」の超世代的連続性を表示する慣習がしばしば見られたとして 反論している2)。

論点の当否は別にして、それぞれの主張の検証をめぐる方法論的な問題点が共通して指 摘できるように思われる。すなわち、両者はともにその主張を裏づける第一次資料による 
検証が十分に行われているとはいえず、民衆の実像の描写がいまだ不十分で、したがって それらの主張の一般化には限度があるように思われる。とりわけ、近代の民衆像に関して、 近世の民衆像からの演繹に基づいて議論が展開されることが多く、いまだ積極的な近代民 衆像の提示には至っていないように思われる ${ }^{3)}$ 。

そこで本稿では、米沢日記という資料の特性を生かして、実在の民衆像を描くことによ り、近世の民衆像からの演繹ではない近代の民衆の実像を提示しょうと思う4)。乙して、 問題とする「家」が近代を生きた弘安にどのように体現されていたのかを、家父長制的「家」 規範からの距離という観点から分析していこうと思う。

そのことを通して、近代が語られるときの民衆の実像の不十分さを少しでも補い、弘安 に代表される民衆にとっての近代を照射していきたいと考えている。そのためのパラダイ ムとして仮説的に次のように設定する（図 1)。

1）明治民法法制化を梃子 として推進された家父長制的

図1パラダイム

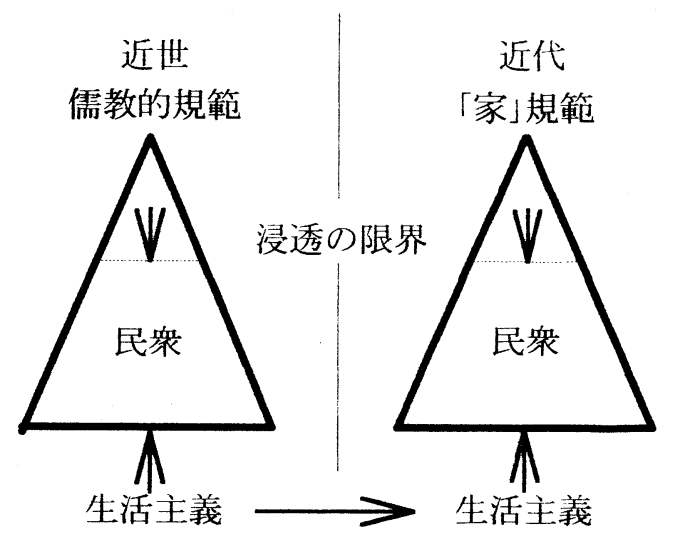

「家」規範も、近世の武士階 級の支配的規範である儒教的 規範も、民衆レベルにおいて は、その浸透は一様ではなか った。

2）民衆にとっては、その 日その日を生き抜くという生 活の事実こそが最も重要な関 心事であった。そのような生 活の事実に根をおろす態度を

「生活主義」とすると、その 「生活主義」は民衆が帰属す る階層 ${ }^{5)}$ や職業によって特

化するとともに、たえず歴史の刻印を受けながらも、非日常的な民衆行事の中においても、 厳然として機能した。

図 1 は、このパラダイムを図式化したものである。「生活主義」は、その内容から歷史 の流れの中で微妙に変化し、時代によって異なりを有するものではあるが、時代による差 異は考察の対象から外れるため、図 1 では便宜上近世も近代も生活主義といら一語で表し た。

本稿で都市職人をとりあげるのは、とくに近代以降、民衆の生活の基盤は都市を基点に 形成され、展開されており、その意味で都市に生きた職人の生活世界の分析は、本稿の仮 説検証の場として適合的であると考えられるからである。 


\section{2. 調査の概要}

米沢日記は、金沢の象嵌職人、米沢弘安 (以下、弘安) が 1906 年から 1972 年に書き残し たものである ${ }^{6)}$ 。日記の量は、69 冊(400 字詰め原稿用紙 4336 枚)にのぼり、その主要部 分は、大正年間に書かれている。大正期は、弘安が 25 歳〜38 歳の、仕事と生活が最も充 実した時期である。日記は、一日の天候を記録することから始まる。次に外出や来客、そ の時刻と用件、家族の外出と行き先などの行為が記される。天皇、軍事、政治などの社会 的な出来事や災害などの事件があれば、それらは簡潔に記される。「感じる」こと「思う」 ことは少なく、それらは、毎年元且に新たな一年の心構えを書くにとどめられ、一日一日 の行動と出来事が淡々と経られている。日記の大半を占めるのは、仕事や製作にかかわる 事柄、家族や親族との人間関係、趣味などの私的な出来事である。

資料的特性として、日記は、書き手の関心に基づいて脚色された事実の記録である。書 き手の関心は、その事実を、あるときは誇張し、あるときは抑制し、あるものは捨てさる。 また記憶違いのこともある。したがって、日記は、事実との関連において限界を持つ。「し かし、それらすべての事実が書き手にとっては『真実』として、書き手の主観的現実を構 成する。この『事実』の加工という事実の中にこそ、書き手の生活世界に対する関係をか いまみることができる」[古屋野・青木，1995，p. 67]。米沢日記の内容や文体からは、自 己規律的な弘安の生活世界が想起される。それは、彼自身の自らの生活に対する距離でも あろう。それが、米沢日記の特徴である。

本稿では、「個人と歷史」の関わりという問題場面を考察するため、米沢日記を資料と して作者弘安の生活世界を中心に分析を試みる7 ${ }^{7}$ 。日記分析は、以下のような手順で行っ た。1. 本稿の目的に沿って仮説的パラダイムを設定する。2.データを分類し、整理する。 3. 仮説検証のための基本的概念の構筑と、その概念の現れ方を見るための分析軸を設定す る。4.コンテクストづけ[水野，1986，pp. 170-171]を行い、日記の生活世界を再構成する。 5. 弘安の生活世界の意味を分析枠組みに照らし、仮説とデータを往復する。6. 日記に登場 した出来事の意味を、時代、社会、個人に照らして解釈する。7. 仮説の検証を行う。なお、 ジェンダーに関わるデータの解釈は、日記の書き手が男性であるといら制約を持つ。記述 された行為や人間関係の取り方は、弘安という男性の目を通して表現されたものである。 したがって、その偏りは否めない。その点を考慮した上で、テーマに沿ったデータの解釈 を行った。日記の分析に際しては、弘安の三女米沢信子氏(金沢在住)への聞き取りを行い、 補完資料とした ${ }^{8)}$ 。さらに、伝統工芸論に基づく弘安の人物伝記 [田中，1974] 生活史再 構成のため補完資料として使用した。弘安の略歴については、表 1 に示す。 
表 1

\begin{tabular}{|c|c|}
\hline 1887(明治20) & 金尽市上斯に生ま九万 \\
\hline $1899(32)$ & 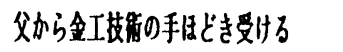 \\
\hline $1904(37)$ & 腣国中学会 (勈信数有)人会 \\
\hline 1917（大正 6) & 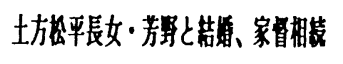 \\
\hline $1923(12)$ & 父清左籍网设 \\
\hline 1928（相 3） & 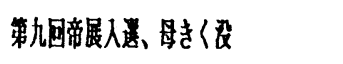 \\
\hline $1948(\quad 23)$ & 三女·启子、根家相裳 \\
\hline $972(47)$ & 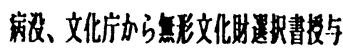 \\
\hline
\end{tabular}

\section{3. 弘安が生きた生活背景と階層}

「日記を書くという行為には、いくつかの階層的な条件が伴う」[古屋野・青木，1995， pp. 66-67]。弘安は、高等小学校卒業後、通信教育 ${ }^{9)}$ で学び、書くことの能力を身につけ ていた。仕事は自宅で行うため、規則的な生活であった。就寝前に一日を振り返り、自省 するという自己規律的な生活習慣を持っていた。それらの条件が、日記を書くことへの関 心となり、習慣となっていった ${ }^{10)}$ 。日記は、無線の大学ノートに万年筆で、時には鉛筆 で毎日丹念に書かれている。その膨大な量の日記そのものが、弘安の生活世界の表現であ り、かつまた、弘安の階層を表しているといえる。

\section{（1）職人としての位置}

弘安の父は、象嵌職人として加賀藩に登用された細工人であった。廃藩後は、金沢市の 職人養成所の棟梁をつとめた。弘安は、12 歳で父に象嵌の技術を伝授された。兄は絵描 きとなって金沢を去り、次男である弘安が家業を継いだ。弘安は、問屋や一般顧客からの 注文で生計を立て、そのかたわら資金を投じて展覧会出品の作品を製作した。この時期は、 伝統工芸界全体が隆盛し、象嵌細工も生活用具の装飾や奢侈品の注文が増えた。

$\lceil …$. 才田様より挨拶あり……回の宮内省御用引受二関し、何分の御援助を願ふとの事

四寸二分盃二千七百個、四寸、四寸五分、五寸の三組五百組にて……當五円にして、

朝七時より夜九時二至儿就業なりと….」(大正 9.2.12、以下大正は省略)。「水辺方二電

話を取られた。千八百四十五円なりと…...11)」(7.3.19)。

才田様は工房の経営者である。「これらの工房では親方は技術者、かつ経営者として、 数多くの徒弟と下請け職人を駆使して製造·販売にあたった」 [田中，1992，p.74]。大正 
9 年、才田工房は宮内省から 4,200 個の盃象嵌の注文を受けた。金属器業組合 ${ }^{12)}$ の職人は、 協力を要請され、こぞって製作にあたった。弘安も一ヶ月あまり才田工房に通った。水辺 様もまた工房を持つ。このような富裕な工房経営者は、「当時、きわめて普及の少なかっ た電話を所有し経営活動を行った」[田中，同］。

ここの頃のように仕事を催促せられし事はない.......休む間もなく攻立るので皆が疲れて居

る。……何れも云訳二困る」(3.3.7)。「……花生、香炉、文鎮の色付二清二と終日掛っ

た。金属展出品物なり」(8.6.8)。

弘安の日常は、注文が多く多忙である。催促に来られたが出来ていない。あわてて夜業 をして仕上げる。展覧会に出品する作品の製作もある。弟清二も象嵌職人であり、分家し た後も弘安のもとに通って仕事をする。共に夜業をするのは日常的である。弘安は、展覧 会や陳列会のほとんどに出品する。「日記書けず……記憶二存するもののみ書き置く次第 なり」(7.12.24) ということもある。

$\lceil\cdots . .$. 金属組合例会……評議員の補欠選挙があり、僕と加賀谷君が当選した。仕方がない から僕も承諾した」(8.4.1)。「金属品展覧会褒賞授与式……生の香炉、才田氏の銅打 出し香炉で県よりも褒賞あたる…(8.6.27)。

弘安は、大正 8 年に、金属器業組合の役員に選出された。組合の長および役員の大半は 工房の経営者である。彼らは多くの徒弟や職人を抱え、金沢の職人を束ねる地位にあり、 経済的には上層の職人である。他方、弘安は自宅の一室を仕事場とする。職人や弟子を持 たず、妻の助言と弟の手伝いを受けるだけであった。そのような状況の中で、弘安の作品 は、多くの賞を受け、作家としての地位を確立した。

(2) 米沢家の家計

「夜八火鉢のカンを清二と一時半頃まで夜業せり。芳野も同しく夜業す」(7.12.20)。「… …吾等壮年期二入れる者はもっとも活動せねばならぬ。……周囲を眺むれば、両親は老 境二入られ共楽二居くあたわず妻子も満足を与へ得ぬ……本年やりたき事は清二の分家 届をする事と其約束の金四百円を渡度事……清二と金を出し合いて文鎮の製造販売を やりたい......其他展覧会、博覧会二は務めて出品する事……(11.1.1)。

仕事は家族の協働を必要とする。妻は、弘安の夜業につきあい、かたわらで内職の仕立 物をする。また、弘安の求めに応じて象嵌の図柄の選定に意見を述べることもある。弘安 にとって、妻は、作品の相談者でもあり、なくてはならない協㗢者である。弘安は、家督 を相続することで、兄と弟に財産分与金を支払うことになった。兄の分は済んだが、弟の 分がのびのびになっている。それが四百円である。文鎮の製造販売で収入を得られないも のかと考える。

「斎藤様へ福録壽の影斗押と鶴の香合とを見せたが、それを売って吳れとの事で、其談判 に行ったのだ。向が商人故值段の取引は中々抜かりはない.......談判は永びく。遂二折合 
をつけて二個で壱百八円で売る事にした」(8.2.7)。「谷庄様へ䉆鹤の香炉を持っていき

買って貪ふ積であったが買って下さらなかった」(12.6.8)。

展覧会では賞を受け、作品の評価は高くなるが、それらの作品は必ず売れるとは限らな い。売れ残ったものは、誰かに買ってもらい、次の作品の資金を作らねばならない。日数 と資金を投入して製作した作品を自ら売り歩く。值切られることもある。売れないことも ある。作家活動の経費の捻出に困った時は、富裕の同業者から借金をすることもあった。

「白米小売值段、金沢一升四十銭に暴騰し、……何処迄上るや知れず……（7.8.3）。「米

価は四十五銭に騰り、下層民は堪えられなくなった。今夜宇多須神社二集合して之より

各米商及富豪へ嘆願ニ出掛たのだとの事。 僕等が帰る時も浅の川大橋上は、澤山の

人が集まって居た……(7.8.12)。

「大正期の前半は、第一次大戦 (1914-18) とロシア革命 (1917) という世界的事件に大き な影響を受けた。第一次大戦で日本は直接戦火を浴びないまま連合国への物資補給を担当 して資本主義の隆盛を迎えた。しかし、好景気はかえって物価の上昇を招き、特に米の買 占めや売り惜しみをあおり」[若林，1992，p. 112]、米の価格は日単位で上昇した。金沢 の米騒動は大正 7 年 8 月である。米価の高騰にあえぐ下層市民 3,000 人が米穀商に赴き、 米価の值下げを談判した ${ }^{13)}$ 。弘安は、米の価格が気になる。值上がりのあるたびに、日 記に記す。しかし、米騒動には距離を置く。

弟子や雇い人を持たない米沢家にあっては、母が月末には得意先へ勘定を取りに行く。 妻は出来た品物をもって注文主へ届ける。しかし、多くの弟子や職人を持つ工房経営者の 場合、その家族、つまり彼らの母や妻が仕事の用件で弘安を訪ねることはない。米沢家の 階層は、それら上層の人々とは一線を画す。また、家産も家の実体すらないその日暮らし の、米騒動の主体とならざるを得ない下層の人々とも異なる。米沢家は、弘安の結婚後、 子どもの誕生、弟の分家、父の死など、出費のかさむ出来事が続いた。借金をすることも あるが、得意先からの注文は殺到し、職人として生計を立てるには困らない。借金もおい おい返済できる。裕福とはいえないが、その日の米に困ることはない。米沢家の生活は、 そのような営みであった。

弘安は、職人と作家の両立性を余儀なくされたが、作家活動は、職人として時代を生き 抜く生活の指針であった。良い作品を作ることは、職人としての誇りとして存在した。そ の誇りが、職人と作家の両立を可能とし、弘安の職人としての生活世界を形成した。

\section{4. 分析枠組み}

1.で述べた仮説的なパラダイムを検証する手がかりとして、ここでは日記分析の枠組 みを提示する。米沢日記には、弘安および弘安を取り巻く人々の生活が記述されている。 その中で特徴的なのは、「家」という「支配的な社会規範からの距離」（以下、「距離化」） 
に関する記述が、日記全体を通して高頻度でみられ、かつ広範囲にカバーされていること である。この事実は、弘安や家族の生活世界が「距離化」をもって営まれていることを示 している。したがって、本稿では、この「距離化」に焦点を当て、それがどのような内容 から形成されており、何に起因するのかに注目する。

そのための分析軸として、三つの概念、《革新性 $><$ 融通性 $><$ 超越性 $>$ を用いる。こ れらは、「距離化」を最も端的に表す概念として、弘安の価值意識を分析するために、日 記の解読を通して抽出された。価值意識とは、弘安や家族の態度を形成し、行為を内発的 に促すような価值の準拠枠をいう。それぞれの概念は、次のように規定される。すなわち、

く革新性> (innovation) とは、新しいもの、未知のものへの挑戦をあらわす概念である。 また、旺盛な好奇心と進取の気質に富んだ合理的かつ「自由 ${ }^{14)} 」$ な開拓精神の中に見ら れる「距離化」を表す価値意識である。それは、通信教育や各種展覧会など、知や美の欲 求を追求する行為や、製作活動における伝統技法の遵守に対する新技法の開拓のうちに、 主として表出される ${ }^{15)}$ 。

く融通性> (elasticity) とは、関係性を表す概念である。また、家族の意思決定や役割 遂行など世代および性別間の役割関係に関連した「距離化」を表す価值意識である。それ は、弘安を軸とした家族内の関係、主に妻芳野との夫婦関係に見られる性別役割とそれに 拘束されず、妻を対等視した弘安のジェンダー認識として表出される ${ }^{16) 。}$

〈超越性> (detachment) とは、支配的な社会規範からの逸脱性を表す概念であり、最 も包括的にとらわれのなさ一般を表す価值意識である。それは、規範意識に縛られない弘 安/家族の合理的な生活態度、主として家族成員各々における行動の自由裁量として表出 される。

三つの概念相互の関係は、図 2 のように<超越性 $>$ を最も包括的な概念として図示され る。すなわち、三つの概念は、それぞれの特徴を持ちながら「距離化」という点で共通の 価值意識を有している。

これら三つの概念、<革新性 $><$ 融通性 $><$ 超越性 $>$ が主として日常行為レベルにおい て表出することから、第二の分析軸として、行為レベルを表す $<$ 日常性 $><$ 非日常性 $>$ と いう概念を設定し、行為レベルの違いと価值意識との関係をみていく。ここで、く瑺性 >とは、日常行為レベルのことで、日々の生活が構成され、反復される「通常」の行為レ ベルにかかわる次元を指す。＜非日常性＞とは、非日常行為レベルのことで、特定の価值 のもと、（家族）集団を強力に統合する儀礼的行為にかかわる次元を指す。具体的には、 冠婚葬祭、年中行事や、国家や天皇にかかわる儀式等をいう。

三つの概念、<革新性 $><$ 融通性 $><$ 超越性 $>$ にって表される「距離化」と、<日常 性 ><非日常性＞という行為レベルとの関係は、図 3 のように図示される。すなわち、日 常行為レベルでは主として「距離化」が前面に現れ、反対に、非日常行為レベルではそれ が背後に退く、という構造が見られる。 
図 2 「距離化」の内包する 3 つの概念の関係図

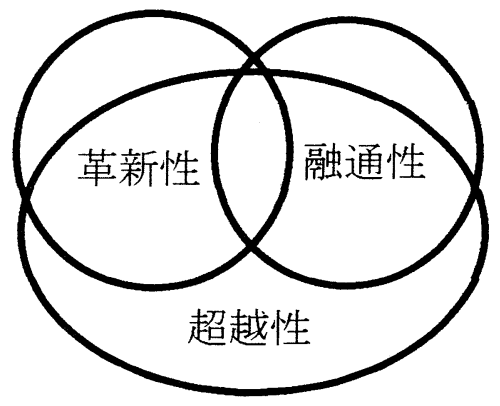

図 3 価値意識の関係構造

日常行為レベル

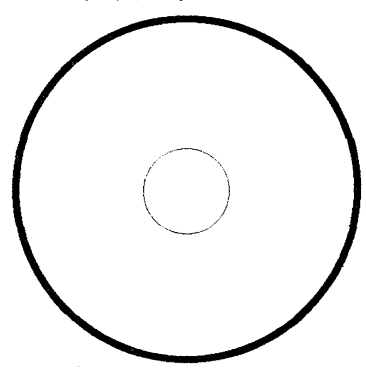

○「距離化」(支配的な社会規範に拘らない価值意識)

「浸透」(支配的な社会規範に拘る価值意識)

\section{5. 弘安の生活様式と価值意識}

5.では、弘安を中心とする「距離化」がどのような形で表出しているのかを、日記の データに基づいてみていく。まず、「距離化」を表す三つの概念がどのような形態で出現 するのかを<日常性＞における弘安の行為を中心に検討する。次に、<非日常性＞におけ る「距離化」を、最後に三つの概念と行為レベルとの関係を、検討する。 


\section{（1）三つの概念}

(1) $<$ 革新性 $>$

く革新性〉は、好奇心と合理的かつ「自由」な開拓精神を表す概念であるが、それは主 に弘安の製作態度において見られる。弘安は、一方では、父から修得した伝統技法を遵守

し、顧客の注文に応じて生活用具を製作するという家計の支柱としての仕事を行った。他 方、象嵌世界の開拓に励み、新たな技法やデザインを開拓して作品を製作した。

「現今の意匠図案界注複雑をきわめて居る。其内二流行がある。吾々に流行二遅る事なく

種々なる物を見それを参考として自分ノ思想を加えて新キジクを出さねばならぬ」

(2.12.3)。

作家として成功するためには、自由裁量と能力主義による新たな着想を必要とする。そ の中で、弘安は開拓精神の発揚を自らに課す。

「東京美術学校教授の……講話ありき。……僕は島田氏二花瓶、盇の模様や形状二付批評

を乞ひ…… (2.12.3)。「夜、図書館へ行き工藝新図や工藝図案を見……時帰る」

(6. 8. 15)。「市主催の意匠図案講習会は本日より十日間にて僕も申込せし事故午前九時頃

迄二行く。…講義八……模様配置法であった……(12.8.1)。

弘安は、新しい技法や図案の研究に精を出す。そのために、仕事の合間をぬって図書館 や展覧会へ行き、講習会へ積極的に出席した。展覧会等への出品はその成果である。弘安 は「職人は一生研究するものにて、多く見、多く聞く方よく、道具市などはつとめて見る ベし。……自己の特徴を発揮して、一寸人の出来ぬなるを作り出せ……品物は人の長く 見るものを造れ」（3.2.22）という先輩職人の言葉に感銘を受け、それを実践する。金沢 の伝統工芸界が全体的に隆盛した時期にあり、講演会や講習会は頻繁に開催された。弘安 はそれらに出席し、学び、批評を求めた。

「(象嵌の)模様とかそんなんは一緒んなって考えてたみたい。キセルの模様考えとって、

そしたら母が春夏秋冬紫煙を絶やさずって、どうかねって。そりやいいよねって」 ${ }^{17)}$ (米

沢信子氏聞き取り、1998,6.9)。

講演会等に出席して教えを受けるだけでなく、日常的には積極的に妻に製作上のアドバ イスを求める等、貪欲に求め吸収し、合理的かつ「自由」な製作態度をとった。

(2) <融通性>

ここでは特に弘安のジェンダー認識に関わる夫婦関係に焦点を当て、家業の協働と家族 経営の観点から検討する。

「指輪、根掛、かんさし等出来二付午后芳野二持たして届く」(7.2.24)。「土方のお父様 お尋ねくだされた。林屋様に屏風金具の注文ある故、行ってくれという事であった」

(7.2.10)。「夜業、屏風金具のトギを芳野と共二一時半迄掛る」(10.2.11)。

弘安は、作品製作以外の時間は象嵌職人として注文品の製作をしていたが、出来た注文 品を届けに行くのは母や妻の役割であった。仕事が立て込み弘安が夜業をするときは、芳 
野もしばしば仕事の手伝いをする。また芳野は、実家の父に新しい顧客を紹介してもらっ たり、後年は作品製作の資金を援助してもらったりする。芳野の父は店を構え、職人と弟 子を抱える富裕な職人 (表具師)である ${ }^{18)}$ 。芳野は実家の父親の社会的力や経済力に依存 して協力や援助を依頼し、弘安はそのような芳野の行為や妻の実家からの援助を受容する。

芳野は、結婚後すぐに内職の仕立物をはじめている。仕立物は当時の主婦の一般的な内 職であった[遠藤，1985，p. 129]。はじめは親戚や知り合いからの頼まれ物であった。そ の後、商工会議所で裁縫の講習会が開かれ、芳野は「明日より出席したし」と一週間通う。

「今日、男女袷、羽織綿入法、帯等を習いたるなり。第二回は……ちち目なしの縫い方、

コート仕立て方、袴等なりと。これも行く事にした。又奥田式の予約もしてきたと」

(10.11.14)。「本日切れ目なしの縫い方を習ってきた」(10.11.17)。

弘安は、芳野の講習会に関心を持ち毎日日記に記述する。後年、生活が逼迫したときに は、芳野はその技術で生計を支える ${ }^{19)}$ 。新しい裁縫の技術習得は、芳野の仕立物に対す る積極的な意思を表し、それは芳野自身の自己決定によってなされた。弘安はそのような 妻の意思を進んで受容している。そこには、夫に依存しない妻の自立した側面と妻の生き 方を許容する夫の自律的態度を見ることができる。

職人でもあり同時に作家でもあった弘安の仕事は、芳野の協働なくしては成立し得なか った。芳野は、経済面での稼ぎ手としてのみならず、作品の批評者として、また作品製作 の根幹を成すデザインの相談者として、重要な位置を占めていた。

芳野の象嵌を補助的に手伝ったり、出来あがった品物を届けたり、内職をしたりという 協働は、必然性を持った現実の生活の必要性に基づく「生活主義」的な行為であるといえ る。それは全面的に夫の経済力に依拠することができない経済状況であるという階層的要 因に規定されている。そのような中での家業の協働は、家族経営体を形成し、そこでは、 性別役割分業は、家業の中で解体されていく側面を有していたといえる。

(3) <超越性>

ここでは、弘安の物事に対するとらわれのなさ（合理性）と家族成員の行動の自由裁量 の観点から検討していく。

「母は髪結二行かれしが、日暮れ共帰って来られない。……仕方がないので、清二(弟) と 二人で鱗汁を作って夕食をおわる」(4.1.17)。「芳野は気分晴れぬ故、お里へ行き新築家 屋など見れば気も晴るかも知れぬ故泊りにやって呉れとの事で、午前九時頃行った」

(7. 8. 29)。

母は、時に夜になっても帰宅しないことがある。芳野も頻繁に外出する。主な外出先は 実家 ${ }^{20)}$ であり、髪結いや寺社参詣のついでにしばしば実家へ立ち寄る。午前中に出かけ て実家で昼食をすませ、夕方帰宅することは度々であり、芳野が子どもをおいて行き、弘 安が守をすることもあった。また病気で通院の必要が生じたときは、赤ん坊ともども長期 の里帰りをする。 
「午前芳野は喜代子 (長女) と鬼子母神へ参詣二行き次手二髮を結ってお里へ寄り午后三時 頃帰る。母は充分ならず終日寝て居られた」(10.7.8)。

鬼子母神は芳野の結婚以前からの信仰で結婚後も毎月参詣している。母が終日病気で寝 ているにもかかわらず、芳野は長時間外出する。このことが、ごく自然な日常として弘安 によって語られる。家族は、各自ばらばらに「勝手」に外出し、帰宅する。弘安は、妻や 母の外出場所や外出の理由は把握しているが、拘束はしていない。

「今朝土方様 (妻の実家)が来て起された故、何事かと戸を開ければ、今朝三時、芳野が分 婏なし、女の子であると。……僕は早速電車で行く。……父が䚻られると母が来られた。 ……夜僕と清二(弟) と行き、後より母も来られた。……夜三階でお酒が出た。一同帰ら れ、僕と母が夜伽をなしお父様お母様も疲れて居らるから休んで貪った」(8.4.26)。「母 は明るくなると㑇へ焚き付けなどすると、お母様もお父様も起られた。疲れて居らるか ら起きは大儀であったろう。芳野が起こしたのだと。僕は一夜寝ずに赤児の守をする。

下に置くと泣き出すから仕様がない」(8.4.27)。

出産、子どもの祝いの席を妻方の実家で用意する。子どもの誕生をめぐるこのような妻 方の行為は、妻と実家とのつながりという民衆レベルにおける慣習と深い関連があり、妻 の実家への依存度の高さを示しているといえる[長岡，1975，pp. 208-218]。

実家での出産時に弘安と母が泊まりこみ、疲れている妻の両親に休んでもらい、弘安が 一晚中寝ないで子どもの守をし、母が芳野の実家で翌朝の食事の用意をして帰る。一晚中 子どもの守をする弘安には、夫の権力に依拠した「家」は見られない。

芳野と実家との関係には、近世からの生活習慣にみられる伝統的な慣習である女性と実 家との結びつきの親密さがみられる ${ }^{211}$ 。実家から贈答品が多い。長女誕生に際しては乳 母車や縮緬の着物など高価なものが届けられる。誕生祝も実家で盛大に行われる。病気の ときは実家へ帰って養生する。実家は大きな後ろ盾になっている。芳野にとって家とは単 に婚家ではなかった。むしろ婚家は、実家との連続性の上に観念されていたことがわかる。

弘安や母にとっても、両者は線引きして序列関係をつけるものではなく、むしろ双方に 開かれた存在で、米沢家との連続性の上に芳野の実家が観念されていた面が窺え、米沢家 と妻の実家とは共存的な側面を有していたと考えられる。それは、実家への依存度の高い 芳野のみならず、長女出産時における弘安や母の行為の中にも厳然と存在していた。

（2）三つの概念と日常行為——非日常性〉との対比において— (1)<非日常性 $>$ のの「距離化」

5.の（1）で、三つの概念、<革新性 ><融通性 $><$ 超越性 $>$ 、すなわち、日常行為 レベルにおける「距離化」についてみてきたが、非日常行為レベルではどうだろうか。

「御大禮の当日は来りぬ。……午後三時三十分号砲轟く。宅二八父を始め、一同階上の陛 下の御影前にて万歳を三唱した」(4.11.10)。 
非日常行為レベルでは、天皇が、前面に押し出される ${ }^{22)}$ 。また、日常行為レベルでは、 相対的に記述の頻度の少なかった父が、他の家族を差し置いて出現する。ここに、「距離 化」と反対ベクトルである「支配的な社会規範の浸透」（以下、「浸透」）を読み取ること ができる。

「元旦! なんとなく新しい心持になる。特に本年は、御諒闇の雲、全く晴れ、国民は先帝 の御威徳を感謝すると同時に又、今上陛下の御愛撫を有り難く思わねばならぬ……僕は 先ず冷水をかむり摩擦をやる。八時安江神社へ詣ず。九時半、お雑煮を祝ひ……家内壱 同健全なるを喜ぶ」(3.1.1)。

しかし、天皇を語りながら家族が出現するのは、弘安にとっての関心が、むしろ日常的 な家族 (の健康)の方に置れていたことを示しており、「浸透」の中の「距離化」を暗示す る。

自宅にて婚礼の式 :「嫁は先づ内佛へ参拝し、次に座敷へ通し、小生も其処ニ出で、嫂つ る子様 (兄佐吉の妻)の酌にて、例の三三九度とかの式を上げた」(6.11.16)

非日常行為レベルでも、私的な儀式になると、「浸透」の中の「距離化」が、よりはっ きりした形で具現する。すなわち、一方で、結婚を嫁取りとする形式を踏みながら、他方 で「例の三三九度亡か的」といった不謹慎ともいえる弘安の態度が表出する。このような 態度の中に、形式には従うが、それほど重要視はしないという弘安の重点の置きどころが、 正直に現れている。

(2)三つの概念と行為レベル

今まで見てきたように、「距離化」は主として日常行為レベルにおいて出現し、「浸透」 は主として非日常行為レベルにおいて出現する。言い換えるならば、＜日常性＞＜非日常 性>という行為レベルの違いが、「距離化」と「浸透」という全く逆方向のベクトルを抱 え込む構造になっている。

すなわち、図３で図示したように、日常行為レベルにおいては「距離化」を現す価值意 識である三つの概念、<革新性 $><$ 融通性 $><$ 超越性 $>$ が前面に現れ、反対に、非日常行 為レベルにおいては、それらが背後に退いて「浸透」が前面に現れるという関係が構造的 に成立している。しかしながら、米沢日記において特に注意を要するのは、非日常行為レ ベルにおいても、「浸透」の中に「距離化」が厳然と存在する点である。

\section{6. まとめ}

ここではまず、5．でみてきた「距離化」が何に規定されていたのかについて考察し、 そして、そのことを踏まえた上で、1. で仮説的に設定したパラダイムに戻って考察を試 みようと思う。

まず、「距離化」を三つの概念別に考察する。＜革新性〉は、象嵌世界の開拓のための 
合理的かつ「自由」な製作態度のうちに表出していた。これは何でも採り入れるという弘 安の進取の気質に負うところが大きい。この進取の気質は、青年期の通信教育受講に代表 される知的欲求や製作欲求に動機付けられており、博覧会や展覧会といった新たな知的枠 組みや世界認識の変化といった弘安の生きた時代性と関連すると考えられる。

＜融通性＞は、弘安のジェンダ一認識として表出していたが、これは家族経営における 芳野の位置に起因するところが大きい。弘安のジェンダー認識に見られるとらわれのなさ は、協働を余儀なくされる家族経営の中で必然的に形成される側面を持つ。それは、階層 的要因、すなわち、現実を生き抜くという生活の重圧に規定される「生活主義」に起因す るところが大きい。しかし、作品製作の根幹に芳野が関与したという事実はこれだけでは 説明し切れないであろう。妻の能力を認めて助力を仰ぐという弘安の気張らない「自然」 な生き方は、生活主義的な要素や上述した時代性、「既存のままを受容する」という意味 での後述する慣用的要素も絡んで醇成されたものであろう。

＜超越性>は、弘安のとらわれのなさや家族の行動の自由裁量として表出していたが、 これは、いわゆる個が確立された近代的な自由とは異なって、婚家と実家の連なりに見ら れるような共存的一体感に支えられた家業推進のための「自由」であった。これは民衆レ ベルで存在していた共存的な生活様式に規定されており、慣習的なものであった。

次に、パラダイムに関連して以下のことが導かれよう。すなわち、「距離化」と「浸透」 の分析から、「家」の浸透には、「距離化」に反比例して強弱があるということができる。 このことは、民衆は、支配的な社会規範とは別の次元を生きており、権力と同じ速度で歴 史を歩むものではないという事実を表している。そして、その過程は、5．で言及した弘 安の生活世界に見られるように、日常的生活の確立を梃子とする歩みであることを示して いる。

弘安の行為が、生活主義や慣習に規定されており、それらが階層や職業によって特化さ

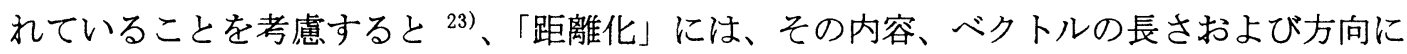
異なりがあり、したがって「支配的な社会規範」の浸透も、一様ではなく階層的あるいは 職業的に多様化していると考えられる。このことは、民衆の位相により近代への適応の仕 方が一様ではなかったという事実を示唆している。

日本の「近代」は、明治から始まるとされるが、民衆は、新しい時代の到来とともに新 しい生活や新しい制度の中で生きたのではない。弘安の行為に見られるく革新性>の知的 製作欲求やく融通性 >の妻との対等的関係に見られる個の萌芽のように、結果的に新し い方向になっているということはあったが、民衆の生活は、むしろ「生活主義」や慣習に 規定され、時代性を内包しながら、過去との連続性と次代への移行の中で営まれていた。

米沢日記の分析は、時代と階層を限定した近代の都市民衆研究に向けたひとつの事例研 究であるが、仮説的に提示した歴史認識のパラダイムの検証はまだ十分であるとはいえな い。しかし、日記に残された一職人と彼を取り巻く人々の生き方の分析から帰結される人 
間生活の実態と理念は、都市民衆史、女性史、さらには日本近代史を再考し、豊かなもの にするひとつのステップとして意味を持つものであると信じている。

(注)

1）象嵌とは鉄や銅の生地に細い金属線を埋め込み文様を作る金属工芸である。江戸時代は象嵌工 芸は刀剣、武具に限られ、町人、農民には禁止された。

2 ）両者の議論に関して、具体的な資料に依拠しているのは、Kurosu and Ochiai[1995]の「家意 識が希薄だったといわれる下層農民でも養子を取ってまで家を継がせることも少なくない」のみ である。これは 19 世紀半ば、多摩の養子慣行の実態を統計的に扱ったものである。

3 ）実態を解明した論文として落合 [1996，p. 28]は、真下[1990]や千本[1990]をあげている。女性 史の領域における実証的研究としては、小泉[1993]や横田[1995]等々がみられるが、直接近代を 対象としたものには実態の提示に終始し専門的分析を伴わないものもみられるため、その数は多 くない。

4 ）近代の民衆の実証的研究は散見されるが、近代と「家」という問題関心の中で、かつジェンダ 一論を加味して捉えた研究はいまだ見受けられない。

5 ）本稿では階層も民衆も、厳密な定義に基づく概念ではない。階層とは都市の構造を説明する大 まかな枠組みとして、民衆とは国家や権力との対比で、用いているにすぎない。

6) 米沢日記は、1970 年代、K教授(当時、東京都立大学)が金沢で社会学のフィールド調査の際、 田中喜男氏(金沢在住、歴史学者)より紹介された。田中氏は伝統工芸論に基づく弘安の人物伝記 を著している。その後、この日記を資料として、K教授その他の社会学関係の研究者による研究 [古屋野・青木，1995，等]や、歴史学からの研究がなされている[丸山，1992]。

7 ) 生活史研究の対象者は、社会的カテゴリーの張り付いた個人という側面と、その対象個人の諸 特性という側面を持つ。したがって、生活史研究の場合、個人に担われる歴史の意味の解読とい う典型化と,一個人の生活史という個性化の両方の可能性に向かって開かれている [水野, 1986, p. 188]。

8 ）日記による生活史研究において書き手やその周辺の人々に面接調查をすることで、日記分析を 補完することがある。それは日記面接と呼ばれ、日記世界の一層リアルな再現を可能にする [Plummer, 1983, p. 20] [古屋野・青木, 1995, pp. 67-68]。

9)「米沢弘安は高等小学校を明治 35 年 3 月首席で卒業した。同級生の中には中学校へ進学するも のもあったが、家庭の事情で進学できなかった弘安は、自ら明治 37 年 12 月帝国中学会に入会し た。今日の通信教育にあたるものである」[田中，1974，pp.40-43]。

10）弘安は、自身が日記を書くことについて、その理由や意義を記すことはないが、ただ一度次の ように書いている。雑誌「学生」を読み「其中で、帝国図書館長の日記の書き方を再読す。大人 物は他人が書いて呉れるが、吾々の歴史は自分でつけねばならぬ。後年参考二なる事この上なし とあり。愈愈継続して記さんと決す」(3.1.6)。

11）当時の電話がいかに高価であったかを知るために次のデータを記す。「白米の小売一升三十二 銭五厘となる」(7.5.8)。「水辺様御出あり……清二が手傳二行きし工料を算用するとの事…… 日工料一円、夜業二十五銭の割にて払われた」(7.6.6)。

12）「……組合創立総会……金銀細工、象嵌細工、真鍮鋳物業者……三十八名を以て組織するなり」 (7. 10.25)。金属器業組合創設は、大正 7 年である。 
13）象嵌工芸品に欠かせない金箔製造の箔打は、緎細で高度の技術を必要とする職種である。しか し箔産業は、産業構造の中で景気の変動に影響されやすく、職人は不安定で厳しい環境におかれ た。「米騒動の参加者のうち職業が確実にわかっているのは……騒動の逮捕者・被起訴者の合計 25 人である。その内訳は、箔打職 8 人、日雇い 6 人、人力車夫 3 人、大工 2 人、その他職人 4 人、 その他 2 人である」[若林，1992，p. 121]。金沢米騒動の中心を担ったのは箔打職人であった。

14）ここでいう「自由」とは、近代的自由という意味ではなく、生活行為を自らの関心に沿って自 らの判断で決定するような、いわば「勝手・気まま」の意味である。

15）たとえば、通信教育の受講などは、当時の一般的な教育状況や弘安の家庭の事情(職人後継者 としての父の意向と経済的事情) からすると、例外的であると考えられる。そこには、旺盛な知 的好奇心と開拓精神をみてとることができる。

16）「性別役割」については、女性を家内の私的領域に、男性を稼ぎ手として生産領域に振り分け る公私の分離における性別分業と、家庭内での家事・育児における性別分業の両方をさす。「ジ エンダー認識」としては、弘安には妻を対等的に扱う態度があり、それは旅行や娛楽への同伴や、 作品に対する意見・感想を求めたこと (大正期以降)にも表出される。この意味では革新的とさえ 言える。

17）弘安が妻にアドバイスを求める記述は大正期以降である。本稿は大正時代に限定しているため 聞き取りを引用する。春夏秋冬の文字が象嵌されたキセルは、現在安江金箔工芸館 (金沢市)に展 示されている。

18）「土方松平氏 (芳野の父) は名表具師として知られ…経済的にも豊かであったから趣味人、来客 の出入りが多かった……弘安にとって松平は、義父であると同時に仕事のよき理解者であった。 弘安が……材料費の捻出に困っているときは、芳野さんを通してしばしば資金援助に及んだ」[田 中, 1974, pp. 46-47]。

19）「初めは親戚、知り合いのとか頼まれて縫ってて、そのうちだんだん苦しくなると、お弟子さ ん、5〜6人娘さん集めて教えてたみたいです」(米沢信子氏聞き取り、1998.6.9)。

20）大正 10 年に芳野が実家へ行ったのは、4 日に一度の割合、髮結いは $6 \sim 7$ 日に一度。そのう ちほぼ $1 / 3$ は夜の外出である。実家へ泊まりに行ったのは、7回。延べ 15 日間である。その他 の年もほぼこれと同じである。

21）明治期、伝統的な生活習俗を野蛮や非合理として取り除き始めたが、そのとき出された国・県・ 郡の通達、申し合わせを見ていくと、当時の女性の暮らしの一端をうかがうことが出来る。例え ば、新潟県が 1876 (明治 9 ) 年に出した通達には「三日から数日にもわたった伝統的な結婚式やそ の後の娘の実家との付き合いが娘を持った家にとって経済的に大きな負担になっていることを問 題にしている」。このことは同時に「女が結婚によって夫の家にのみ帰属するのではなく事ある ごとに実家に依存し、特に経済的な援助を受ける習慣が存続していた」事実を表している [永原， 1990, pp. 55-56]。

22）「国家レベルの天皇と国民の関係が、家族レベルの父母とその子孫の関係のアナロジーとして 捉えられるという『家』を基盤とした国家像」が浸透していると考えられる [伊藤，1982，pp. 89]。

23）生活の必要性から生まれる「生活主義」や、世代を超えて継承される慣習は、極端に言うなら ば、協働を必要とする層と必要としない層、また家の実体すらないその日暮らしの層とでは、当 然その質を異にする。 


\section{文献リスト}

有地亨. 1977. 『近代日本の家族観 明治篇』弘文堂.

有賀喜左衛門. 1970. 『有賀喜左門著作集 第九巻 家と親分子分』未来社.

遠藤元男. 1985. 『日本職人史の研究IV 職人と生活文化』雄山閣.

伊藤幹治. 1982.『家族国家間の人類学』ミネルヴァ書房.

神島二郎. 1961.『近代日本の精神構造』岩波書店.

川島武宜. 1965. 『日本社会の家族的構成』日本評論社.

喜多野清一. 1976. 『家と同族の基礎理論』末来社.

小山静子. 1995.「家族の近代 明治初期における家族の変容」西川長夫・松宮秀治編『幕末・明治

期の国民国家形成と文化変容』新曜社: 167-189.

古屋野正伍. 1979.「伝統産業技術と職人の役割」『国連大学人間と社会の開発プログラム研究報告』

国際連合大学: 2-23.

古屋野正伍・青木秀男. 1995. 「日記における『個人対歴史』の問題」『人間科学論究』3:65-76.

Kurosu, S. and Ochiai, E. 1995. “Adoption as an Heirship Strategy under Demographic

Constraints.” Journal of Family History 20 (3) :261-288.

真下道子。1990.「出産・育児における近世」女性史総合研究会編『日本女性生活史近世』東京大学 出版会.

丸山敦. 1992.「象嵌職人にみる明治期の遊楽」『ホワットイズ金沢 金沢学 4』:101-146.

丸山真男. 1996.『日本の思想』岩波新書.

水野節夫. 1986. 「生活史研究とその多様な展開」青井和夫監修/宮島喬編集『社会学の歴史的展開』

サイエンス社.

牟田和恵. 1996. 「日本型近代家族の成立と陷突」『家族の社会学』岩波書店.

永原和子. 1990.「民族の転換と女性の役割」『日本女性生活史近代』東京大学出版会.

長岡博男. 1975. 「民俗と生活感情」『加賀能登の生活と民俗』慶友社.

落合恵美子. 1989. 『近代家族とフェミニズム』勁草書房.

落合恵美子. 1996. 「近代家族をめぐる言説」『家族の社会学』岩波書店.

Plummer, K. 1983. Documents of Life: An Introduction to the Problems and Literature of a

Humanistic Method. George Allen \& Unwin Ltd. (原田勝弘他訳『生活記録の社会学』光生 館, 1991 年).

瀬地山角. 1997.「家父長制をめぐって」江原由美子編『フェミニズム論争』勁草書房.

千本暁子. 1990.「日本における性別役割分業の形成 家計調查をとおして」荻野美穂他『制度とし

ての女』平凡社.

田中喜男. 1968. 『百万石の職人』北国書林.

田中喜男. 1974. 『加賀象嵌職人』北国出版社.

田中喜男. 1993.『伝統工芸職人の世界』雄山閣.

上野千鶴子. 1990。『家父長制と資本制』岩波書店.

上野千鶴子. 1994. 『近代家族の成立と終焉』岩波書店.

柳田國男. 1963。『定本柳田國男集第 24 巻 明治大正史世相篇』筑摩書房: 120-414.

横田冬彦. 1998.「鹿子絞の女たち」京都橘女子大学女性歴史文化研究所編『家と女性の社会史』.

横山源之助. 1990.『日本の下層社会』岩波書店.

若林喜三郎監修. 1992.『激動の地方史』北陸放送株式会社. 
本稿は、1998 年 7 月、第 16 回日本都市社会学会大会における、古屋野正伍、青木秀男、坪田典 子、水越紀子の四人で行った共同報告「近代都市職人の生活世界」に基づいて書かれたものである。

(つぼた みちこ/都市社会学研究所)

(みずこし みちこ／都市社会学研究所） 